OPTIMUM. ECONOMIC STUDIES NR 2 (92) 2018

\author{
Mgr Piotr Zbigniew ŻUKOWSKI \\ Wydział Ekonomii i Zarządzania, Uniwersytet w Białymstoku \\ e-mail: patxilopezurki1998@onet.p1
}

DOI: 10.15290/oes.2018.02.92.14

\title{
WPLYW KONIUNKTURY GOSPODARCZEJ NA STAN FINANSÓW PUBLICZNYCH JAPONII
}

\begin{abstract}
Streszczenie
Japonia przez wiele dekad była uważana za wzór gospodarczy dla innych krajów Dalekiego Wschodu. W ostatniej dekadzie XX wieku gospodarka japońska popadła w głęboką recesję, co objawia się systematycznie rosnącym poziomem zadłużenia wewnętrznego sektora finansów publicznych. Na skutek nieustępującej stagnacji gospodarczej status Japonii jako mocarstwa gospodarczego Dalekiego Wschodu wydaje się być zagrożony w niedalekiej przyszłości. Rząd Japonii od lat konsekwentnie prowadzi rozbudowaną politykę społeczną, skierowaną przede wszystkim do osób w wieku emerytalnym. Od początku lat dziewięćdziesiątych, mimo stagnacji ekonomicznej, poziom życia Japończyków wzrósł diametralnie, czego dowodem jest fakt, iż w Japonii obecnie mieszka najliczniejsza na świecie grupa ludności w wieku 100 i więcej lat. Szybkie w skali światowej starzenie się społeczeństwa może w przyszłości bardzo negatywnie wpłynąć na stan zadłużenia państwa. Od lat dziewięćdziesiątych XX wieku kolejne rządy Japonii bezskutecznie szukały sposobu wyjścia z recesji gospodarczej, a także zmniejszenie długu publicznego.
\end{abstract}

Słowa kluczowe: silver economy, dług publiczny, polityka migracyjna, polityka społeczna

JEL: F63, G01, H60, J11

\section{THE INFLUENCE OF JAPENEESE ECONOMIC SITUATION ON JAPAN PUBLIC FINANCES CONDITION}

\section{Summary}

For many years Japan has been considered as an economic pattern for others Asian countries. In last decade of XX century Japanese economy has fall into recession phase, what shows in systematic growth of national debt. In result of permanent economic recession, Japanese position as an economic force of East Asia seems to be endangered in common years. Japanese government from many years purposes expanded social policy, addressed mostly to pensionary people. Since of early 1990s, though the permanent stagnation, life rate of the Japanese has growth diametrically, what sign is fact, that today in Japan lives the biggest in the world population of people in the age of 100 and more. Fast-moving aging of Japanese community could affect level of national and foreign debt negatively in the future. Since 1990s XX century next Japanese governments unsuccessfully tried to work against the recession and to reduce government debt.

Key words: silver economy, government debt, migration policy, social policy 


\section{Wstęp}

Japonia pod wieloma względami wyróżnia na tle innych krajów rozwiniętych. Rozwiązania instytucjonalne w gospodarce japońskiej są unikatowe w skali światowej. Przez wiele lat były one źródłem sukcesów gospodarczych tego kraju. Przez trzy ostatnie dekady gospodarka japońska znajduje się w stanie pogłębiającej się recesji z wielu przyczyn zewnętrznych i wewnętrznych, a stan koniunktury znajduje swoje odbicie w stanie finansów publicznych Japonii. Problemem badawczym jest bardzo wysoki w skali światowej dług publiczny tego kraju, przekraczający $200 \%$ dochodu narodowego. Celem pracy naukowej jest analiza wpływu koniunktury gospodarczej na stan finansów publicznych Japonii, a także weryfikacja piramidy hipotez. Główna hipoteza badawcza zakłada, iż główną przyczyną wysokiego poziomu zadłużenia japońskiego sektora finansów publicznych jest rozbudowana polityka społeczna, wynikająca głównie z systematycznie starzejącego się społeczeństwa japońskiego. Pierwsza hipoteza szczegółowa zakłada zdecydowaną przewagę zadłużenia wewnętrznego Japonii nad zadłużeniem zagranicznym tego kraju. Druga hipoteza szczegółowa dotyczy natomiast polityki migracyjnej Japonii i zakłada konieczność otwarcia japońskiego rynku pracy dla cudzoziemców w celu odmłodzenia społeczeństwa.

\section{Polityka gospodarcza Japonii po II wojnie światowej}

Po II wojnie światowej gospodarka Japonii weszła na drogę szybkiego wzrostu, głównie dzięki ogromnej wielomilionowej pomocy finansowej, technologicznej oraz logistycznej Stanów Zjednoczonych. Powojenny sukces gospodarczy tego kraju nie byłby możliwy również dzięki czynnikom endogenicznym, takimi jak skłonność Japończyków do oszczędzania, niespotykanemu w innych regionach świata etosie pracy, konsekwentnej polityce innowacyjnej oraz proeksportowej orientacji gospodarczej firm japońskich. W latach siedemdziesiątych sukces ekonomiczny Japonii powtarzały tygrysy "pierwszej generacji”, czyli Korea Południowa, Tajwan, Singapur i Hongkong, a w następnych latach Chiny Kontynentalne wkroczyły na drogę dynamicznego rozwoju gospodarczego, a w latach dziewięćdziesiątych XX wieku do tego grona dołączyły „tygrysy drugiej generacji", czyli Tajlandia, Malezja i Indonezja. Wszystkie te kraje (oprócz Chin), większość rozwiązań instytucjonalnych czerpały właśnie z doświadczeń Japonii [Grabowiecki, 2009, s. 196-198].

Japonia do lat dziewięćdziesiątych XX wieku była jedynym wysoko rozwiniętym państwem regionu. Do dzisiaj wielu ekonomistów uważa japoński model gospodarczy za wzorzec dla innych krajów Azji Południowo-Wschodniej. Do wczesnych lat dziewięćdziesiątych XX stulecia gospodarka Japonii była $\mathrm{w}$ bardzo dobrej kondycji gospodarczej. Jednak powojenne rozwiązania instytucjonalne i struktura gospodarki japońskiej, które były jednymi z podstawowych czynników powojennego sukcesu gospodarczego Japonii pod koniec XX wieku 
stały się znaczącym obciążeniem dla całego społeczeństwa japońskiego i gospodarki. Wejście na drogę rynkowego systemu gospodarczego nowych krajów Azji oraz Europy Środkowo-Wschodniej w połączeniu z uwarunkowaniami wewnętrznymi spowodowały trwającą nieprzerwanie od wczesnych lat dziewięćdziesiątych stagnację gospodarczą Japonii. Gospodarka japońska bardzo silnie odczuła globalny kryzys z 2008 roku, podobnie jak większość krajów rozwiniętych. Dodatkowo, po 2008 roku Japonię nawiedziły liczne kataklizmy, powodując wielomilionowe straty $\mathrm{w}$ budżecie państwa, załamanie wymiany handlowej oraz pogłębienie recesji. W 2010 roku Japonia przestała być drugą gospodarką świata na rzecz ChRL. Dług publiczny od ponad dekady przekracza 200\% PKB kraju, co w chwili obecnej stawia Japonię na drugim miejscu na świecie, po Grecji, pod względem relacji realnego długu publicznego do PKB. $\mathrm{W}$ związku z trwającym zastojem gospodarczym kolejne rządy Japonii postawiły sobie za priorytet ożywienie gospodarki kraju przez reformę instytucji sektora publicznego [Grabowiecki, 2009, s. 196-201].

W 2014 roku Japonia była czwartym największym eksporterem towarów na świecie oraz siódmym największym dostawcą usług komercyjnych, choć zarówno w przypadku towarów, jak i usług, występował ujemny bilans z zagranicą. Od 2011 do 2015 roku występował duży deficyt handlowy, po ponad 30 latach stałej nadwyżki handlowej, co było spowodowane w pewnym stopniu zwiększeniem importu surowców oraz kataklizmami. W większej części sytuacja $\mathrm{w}$ japońskiej wymianie handlowej jest spowodowana jednak przenoszeniem od lat dziewięćdziesiątych $\mathrm{XX}$ wieku produkcji poza jej granice. Zdaniem autorów, kluczowym zadaniem dla japońskich przedsiębiorstw może okazać się znalezienie nowych rynków zbytu dla eksportowanych towarów i usług, a jako główne motory japońskiej wymiany handlowej wskazują przemysł motoryzacyjny oraz paliwowo-energetyczny [Tomeczek A.F., Tomeczek M., 2017, s. 137-14].

Wcześniej, do mniej więcej połowy lat dziewięćdziesiątych XX stulecia polityka społeczno-gospodarcza Kraju Wschodzącego Słońca opierała się na akumulacji i inwestycji, wydłużaniu czasu pracy oraz niskim poziomie zaangażowania instytucji budżetowych $\mathrm{w}$ rozwój ubezpieczeń społecznych, edukację, opiekę zdrowotną oraz obronę narodową. Władze Japonii jeszcze w okresie dobrej koniunktury, to jest w latach osiemdziesiątych XX wieku prowadziły politykę cięć budżetowych i masowego eksportu, dzięki czemu oszczędności Japończyków stały się $\mathrm{w}$ tamtym okresie głównym źródłem finansowania nadwyżki budżetowej państwa [Grabowiecki, 2008, s. 32-37].

W kolejnej dekadzie nastąpił jednak duży spadek inwestycji przedsiębiorstw i wzrost deficytu budżetowego. Oszczędności Japończyków także zaczęły drastycznie maleć, a spadkowi inwestycji firm japońskich w kraju towarzyszył masowy eksport kapitału za granicę $i$ związane $z$ tym przenoszenie produkcji przedsiębiorstw za granicę. Wzrost zaangażowania kapitału japońskiego na świecie stał się także jedną $\mathrm{z}$ ważniejszych przyczyn pogłębiającej się stagnacji gospodarki kraju. Zmiany $\mathrm{w}$ gospodarce światowej $\mathrm{w}$ końcu XX stu- 
WYKRES 1

Wymiana towarów i usług Japonii z zagranica w latach 1960-2016 (ceny bieżące, mld USD)

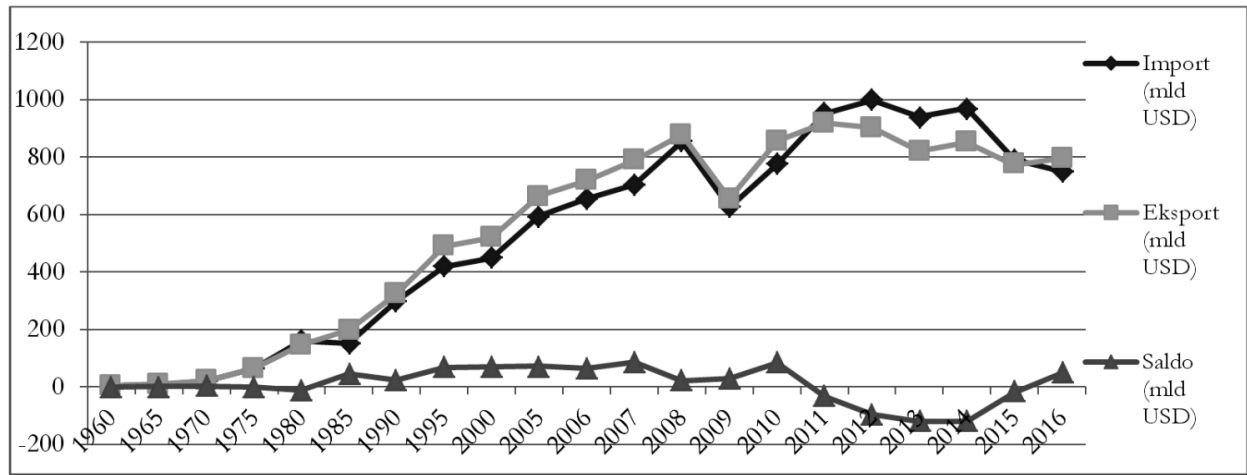

Źródło: [Bank Światowy, https:// data.worldbank.org/indicator/NE.IMP.GNFS.CD?locations=JP, data wejścia: 13.04.2018].

TABELA 1

Przepływy kapitałowe Japonii z zagranicą w latach 2012-2016 (mld USD)

\begin{tabular}{|l|c|c|c|c|c|}
\cline { 2 - 6 } \multicolumn{1}{c|}{} & 2012 & 2013 & 2014 & 2015 & 2016 \\
\hline BIZ w Japonii & 122,4 & 135 & 119,7 & 132,1 & 11,38 \\
\hline Japońskie BIZ za granicą & 1761 & 2358 & 9077 & 128,7 & 145,2 \\
\hline
\end{tabular}

Źródło: [Japonia. Informacja..., 2017, s. 1. Informator ekonomiczny..., 2018].

WYKRES 2

Wzrost nominalnego PKB Japonii w latach 1960-2016

[RDR, \%]

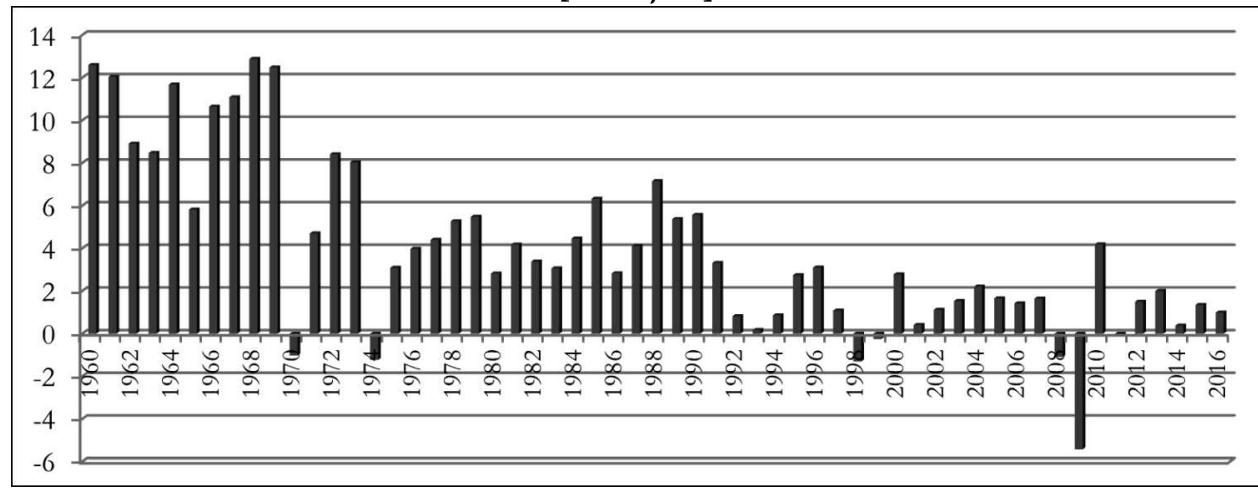

Źródło: [Bank Światowy, https:// data.worldbank.org/indicator/NY.GDP.MKTP.KD.ZG?locatio ns=JP, data wejścia: 14.04.2018]. 
lecia wykazały przestarzałość wielu rozwiązań instytucjonalnych w dotychczasowej polityce gospodarczej Japonii i konieczność gruntownych reform instytucji sektora publicznego. $\mathrm{W}$ latach dziewięćdziesiątych oraz $\mathrm{w}$ pierwszej dekadzie XXI wieku nastąpiły gruntowne zmiany w polityce społeczno-gospodarczej Japonii. Kolejne rządy tego kraju konsekwentnie rozbudowywały sektor ubezpieczeń społecznych, skrócono znacząco czas pracy w japońskich firmach. Radykalnie wzrosły także wydatki budżetowe na ochronę środowiska naturalnego oraz opiekę zdrowotną. Wskutek powyższych działań znacząco podniósł się poziom i jakość życia Japończyków, szczególnie w wielkich aglomeracjach [Grabowiecki, 2008, s. 35-42].

Trwająca od momentu objęcia przez Shinzo Abe w grudniu 2012 roku urzędu premiera polityka antykryzysowa Japonii nosi nazwę abenomiki. W wąskim rozumieniu polega ona na zwalczaniu stagflacji, z którą od lat boryka się trzecia gospodarka świata przez trzy instrumenty: politykę fiskalną, pieniężną i konsekwentną strategię wzrostu gospodarczego. Jej program został szczegółowo omówiony przez premiera Japonii na konferencji prasowej w styczniu 2013 roku. Abenomika w założeniu miała polegać na gruntownej reformie polityki fiskalnej, przez pobudzanie wydatków publicznych oraz zmianach w polityce pieniężnej Japonii, polegających na osłabieniu kursu jena, co w krótkim okresie miało przynieść wzrost wolumenu eksportu japońskiego. Trzecim, równie istotnym filarem polityki jest wspieranie przedsiębiorstw prywatnych przez państwo, co w długim okresie miało zaowocować znacznym ożywieniem gospodarczym, w postaci wzrostu PKB. Abenomika znacząco różni się od polityki realizowanej przez poprzedników Shinzo Abe, opartej na keynesowskich metodach. Jednym z głównych celów nowej polityki makroekonomicznej, oprócz ożywienia gospodarki, miało być zmniejszenie deficytu budżetowego i długu publicznego. Dodatkowym jej filarem jest przyznanie Tokio organizacji letnich igrzysk olimpijskich w 2020 roku. Wstępne szacunki władz miasta mówią o utworzeniu 150 tysięcy miejsc pracy i co najmniej 30 milionach dolarów wydatków na infrastrukturę w stolicy kraju [Grabowiecki, 2014, s. 341-345].

\section{Struktura wiekowa i etniczna społeczeństwa japońskiego}

W krajach cieszących się bardzo wysokim poziomem rozwoju społeczno-gospodarczego coraz większym zainteresowaniem wśród ekonomistów i przedsiębiorców cieszy się silver economy, czyli gałąź ekonomii związana z zaspokajaniem potrzeb osób starszych. Ma to bezpośrednie związek z poprawą poziomu życia obywateli i idącym za tym wzrostem długości życia obywateli oraz znaczenie osób w wieku emerytalnym w życiu społeczno-gospodarczym kraju. Japońska gospodarka stanowi doskonały przykład silver economy, gdyż polityka społeczna i gospodarcza Japonii jest w wielu aspektach poświęcona osobom starszym. Nie ma w tym jednak nic dziwnego, gdyż Japończycy od wielu lat cieszą się najdłuższą średnią długością życia na świecie, a mieszka tam 
najliczniejsza grupa osób w wieku 100 i więcej lat. Społeczeństwo japońskie jednak starzeje się $\mathrm{w}$ bardzo szybkim tempie, a od kilku lat kraj ten cechuje ujemny przyrost naturalny. W 2016 roku w Japonii mieszkało ponad 65 tysięcy stulatków, a w 2017 roku ich liczba przekroczyła liczbę 67 tysięcy. Ludność w wieku produkcyjnym to najliczniejsza grupę demograficzną w Japonii. 26,7 proc. ze 127,11 mln osiągnęło wiek emerytalny. Liczba osób w wieku poprodukcyjnym już na początku XXI wieku przekroczyła liczbę dzieci [https:// businessinsider.com.pl/lifestyle/demografia-japonii-czy-japonczycy-moga-wyg inac/cyw8dec, data wejścia: 01.04.2018 r.].

\section{Struktura wiekowa społeczeństwa japońskiego w 2013 roku [\%]}

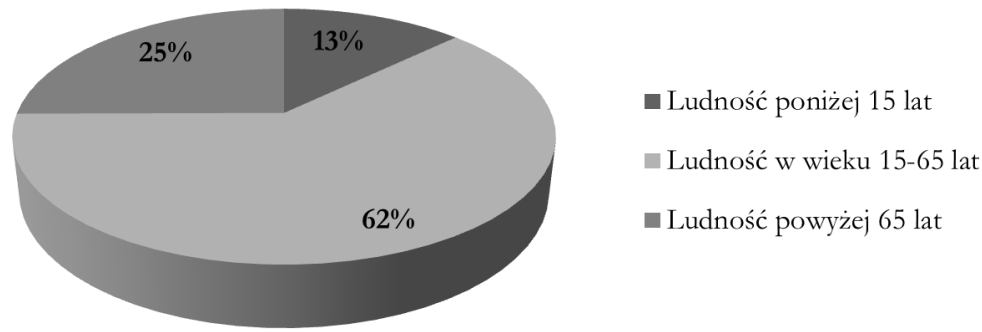

WYKRES 3

Źródło: [Młodawska-Bronowska, 2017, s. 120-121].

Cechą szczególną społeczeństwa japońskiego jest wyjątkowo jednolita w skali światowej struktura etniczna i narodowościowa. Mniejszości narodowe nie przekraczają bowiem 3\% społeczeństwa. Jest to spowodowane głównie przez bardzo restrykcyjną w skali globalnej politykę migracyjną. U schyłku XX wieku Japonia zaczęła powoli otwierać swój rynek pracy dla cudzoziemców, głównie ze względu na już występujący $w$ gospodarce niedobór siły roboczej. Polityka dekasegi rozpoczęła się już w 1990 roku, kiedy to dokonano znaczących reform $\mathrm{w}$ polityce migracyjnej. Wprowadzono wtedy szereg udogodnień dla pracowników z zagranicy. Jednak polityka dekasegi w zdecydowanej większości dotknęła japońskich emigrantów mieszkających głównie w krajach Ameryki Łacińskiej, głównie z Brazylii. Na skutek powyższych działań Japończycy pochodzenia brazylijskiego (jap. Nikkei buraiju-ji, ponad 302 tysiące osób) w latach 1985-2005 byli trzecią najliczniejszą grupą imigrantów do tego państwa, po Koreańczykach i Chińczykach (razem ponad 1,1 miliona osób). Zawierane przez cudzoziemców kontrakty zawodowe nie mogą być zawierane na okres dłuższy niż 5 lat. Mimo bardzo wysokich w skali światowej kosztów życia, praca w Japonii do dziś należy do atrakcyjnych finansowo. W 2010 roku przeciętny pracownik z zagranicy zarabiał średnio miesięcznie 3300 dolarów, co w przybliżeniu daje 3/4 ówczesnej pracy netto statystycznego Japończyka. Poważnym kłopotem jest natomiast brak zapewnionego przez pracodawcę ubezpieczenia 
zdrowotnego oraz fakt, iż pracujący w Japonii imigranci nie są objęci systemem zabezpieczenia emerytalnego [Mydel, Takahashi, 2013, s. 65-69].

Ogółem w latach 1985-2005 liczba imigrantów w Japonii wzrosła z 850,6 tysięcy do prawie 2012 tysięcy. Japońscy imigranci charakteryzują się zdecydowaną dominacją ludności w wieku produkcyjnym (83,7\% w 2010 roku) i nikłym udziałem osób w wieku poprodukcyjnym (poniżej 7\% ogółu ludności). $\mathrm{Z}$ punktu widzenia wieku najbardziej korzystną strukturę mają imigranci z krajów azjatyckich, wśród których udział ludności w wieku produkcyjnym często przekracza 90\%. Zdaniem autora, Japonia powinna prowadzić bardziej otwartą politykę wobec osób innej narodowości, szczególnie mieszkających tam od pokoleń (głównie Koreańczyków i Chińczyków). Poważnym problemem wśród imigrantów w Japonii są często złe warunki pracy oraz kierowanie ich przez władze lokalne do prac poniżej ich kwalifikacji, co nie sprzyja napływowi siły roboczej na japoński rynek pracy. Prognozy demograficzne z 2010 roku przewidują, iż do 2050 roku liczba ludności aktywnej zawodowo w Japonii spadnie aż o 63,6\% [Mydel, Takahashi, 2013, s. 68-71 i 77-80].

W brytyjskim filmie dokumentalnym Wielka Japońska Emerytura dosyć dobrze ukazane zostały współczesne trendy wśród Japończyków. Po II wojnie światowej gwałtownie wzrosła aktywność zawodowa kobiet, zmalała za to liczba małżeństw i urodzeń. Bardzo wysoki stopień komputeryzacji i zainteresowanie tak zwaną Mangq i Anime (japońskie komiksy i seriale animowane) jest zdecydowanie wyższy wśród mężczyzn. Jak można dowiedzieć się z niektórych wywiadów przeprowadzonych w filmie, część mężczyzn woli życie wirtualne od realnego, co siłą rzeczy przekłada się na spadek liczby zawieranych małżeństw i urodzeń oraz wzrost liczby rozwodów [This World: The Great..., 2013].

\section{Polityka społeczna i rozmiary sektora publicznego w Japonii}

Od początku lat dziewięćdziesiątych XX wieku, mimo ciągłej stagnacji, nastąpiły także pozytywne zmiany $\mathrm{w}$ japońskim systemie społeczno-gospodarczym. Zdecydowanie wzrosły wydatki publiczne na szeroko rozumianą politykę społeczną, przede wszystkim wobec osób starszych, dzięki czemu radykalnie podniósł się poziom życia Japończyków w porównaniu do poprzednich dekad. Wzrosły znacząco też wydatki na obronę narodową i bezpieczeństwo publiczne, co znacznie poprawiło poziom bezpieczeństwa obywateli. Japonia posiada najdłuższą ze wszystkich krajów Azji Południowo-Wschodniej historię rozwoju polityki społecznej, sięgające okresu międzywojennego. Najszybszy jej rozwój nastąpił jednak dopiero po II wojnie światowej, częściowo pod aspiracjami Aliantów. Pewne podstawy współczesnej polityki społecznej Japonii powstały jeszcze w okresie Wojny na Pacyfiku, kiedy to upowszechniły się ubezpieczenia emerytalne i zdrowotne wśród wszystkich grup społecznych. Po II wojnie światowej kontynuowano jej rozwój, przy czym zdecydowanie spadło znaczenie wolontariatu w polityce społecznej Japonii na rzecz państwowych instytucji. 
Zdaniem autora Japonia posiada najlepiej rozwinięty system opieki społecznej wśród wszystkich krajów Azji Południowo-Wschodniej, przy czym jest on o wiele mniej powszechny, niż w krajach Europy Zachodniej, czy Australii [Pieliński, 2013, s. 99-105].

Japoński system emerytalny składa się z Emerytury Podstawowej i Pracowniczego Ubezpieczenia Emerytalnego oraz szeregu ubezpieczeń nieobowiązkowych i obejmuje on wszystkie osoby zatrudnione oraz ich małżonków. Japonia jest też pierwszym krajem azjatyckim, który wprowadził powszechny system ubezpieczeń zdrowotnych. $W$ ramach wszystkich systemów ubezpieczeń społecznych wszyscy obywatele muszą sami finansować 30\% kosztów leczenia, z wyjątkiem dzieci poniżej wieku szkolnego oraz osób w wieku 70 i więcej lat $(20 \%)$. Do dziś polityka społeczna Japonii opiera się na ustawie z $1950 \mathrm{roku}$, pomimo wielu reform, Każdy obywatel Japonii ma zagwarantowane prawo do pomocy ze strony państwa, lecz kryteria pomocy społecznej pozostają restrykcyjne. W myśl ustawy pomoc finansowa od państwa ma pokrywać tylko część kosztów pomocy społecznej oraz wspierać własne starania jednostki w celu usamodzielnienia. Podobną politykę społeczną prowadzą tygrysy azjatyckie [Pieliński, 2013, s. 105-107 i 110-113].

$\mathrm{Na}$ rozmiary japońskiego sektora publicznego i jego rolę $\mathrm{w}$ gospodarce można patrzeć $\mathrm{z}$ dwóch stron. $\mathrm{Z}$ jednej strony, udział wydatków budżetowych w PKB, w porównaniu $z$ innymi krajów OECD nadal utrzymuje się na względnie niskim poziomie. $Z$ drugiej strony jednak, sektor ten jest o wiele bardziej rozbudowany niż $\mathrm{w}$ innych krajach regionu. $\mathrm{W}$ strukturze wydatków budżetowych tradycyjnie dominują wydatki na ubezpieczenia społeczne i obsługę stale rosnącego długu publicznego. Wzrost wydatków na ubezpieczenia jest spowodowany przede wszystkim bardzo szybkim w skali światowej procesem starzenia się społeczeństwa. Mimo bardzo niekorzystnych prognoz demograficznych, Japonia pozostaje konsekwentna w polityce migracyjnej, co w perspektywie najbliższych kilkudziesięciu lat może spowodować drastyczny spadek liczby ludności w wieku przed- i produkcyjnym na rzecz osób w wieku emerytalnym, a to będzie się wiązało ze wzrostem wydatków na opiekę społeczną oraz spadkiem dochodów podatkowych budżetu państwa [Młodawska-Bronowska, 2014, s. 151-153].

W 2012 roku w strukturze wydatków z długu publicznego Japonii ponad $29 \%$ ogółu zajęły wydatki na ubezpieczenia społeczne, a prawie 1/4 wydatków były związane z kosztami obsługi długu publicznego. Niewiele mniej, bo 23,1\% na oświatę, kulturę obronę kraju, podczas gdy subwencje dla jednostek samorządu terytorialnego nie przekroczyły 19\% wydatków z długu publicznego. W okresie 1960-2012 nastąpił bardzo duży spadek udziału nakładów na roboty publiczne, z 17,4\% do zaledwie 5,1\% oraz wydatków na oświatę, kulturę, obronę kraju z aż 51,2\% do niespełna $1 / 4$ ogółu. W ciągu tego okresu wzrosła znacząco rola ubezpieczeń społecznych oraz obsługi zadłużenia krajowego, które na początku lat siedemdziesiątych XX wieku stanowiły zaledwie 3,5\% wydatków publicznych. Autorka tekstu podkreśla krytyczny stosunek wielu eko- 
nomistów do ekspansywnej polityki fiskalnej Japonii, zwracając jednak uwagę na drastyczny spadek podaży kredytu w prywatnych bankach pod koniec lat dziewięćdziesiątych XX wieku oraz bardzo niskie w skali światowej bezrobocie, którego ogólna stopa w latach 1960-2012 nigdy nie przekroczyła 6\%. Richard Koo w jednej ze swoich publikacji naukowych, The Holy Grail of Macroeconomics: Lessons from Japan's Great Recesssion Up, Singapore 2009 podkreśla kluczowe znaczenie kryzysu z 2008 roku w utrzymaniem stagnacji gospodarczej kraju. Zdaniem ekonomisty, w okresie 2002-2008 nastąpiła poprawa koniunktury i możliwe, że gdyby nie nastąpił krach w światowej gospodarce, Japonii udałoby się odrobić straty gospodarcze $\mathrm{z}$ lat dziewięćdziesiątych [Młodawska-Bronowska, 2014, s. 151-157].

Do początku lat dziewięćdziesiątych poziom bezrobocia w Japonii kształtował się na niemal zerowym poziomie. Wraz z początkiem ostatniej dekady XX wieku zaczęło gwałtownie przybywać osób bez pracy, głównie z powodu przenoszenia przez japońskie przedsiębiorstwa produkcji poza granice kraju oraz postępującymi procesami technologicznymi w gospodarce światowej. W związku ze znacznym wzrostem bezrobocia w Japonii, konieczne było zbudowanie spójnej polityki rynku pracy. Mimo iż znaczenie własności państwowej $\mathrm{w}$ gospodarce japońskiej jest ciągle nieduże, a poziom bezrobocia w Japonii jest znacznie niższy niż w wielu krajach OECD, jednym z priorytetów obecnego rządu japońskiego jest tworzenie jak największej liczby nowych miejsc pracy [Grabowiecki, 2006, s. 191-201 i 241-256].

WYKRES 4

Stopa bezrobocia $w$ Japonii w latach 2001-2017 [\%]

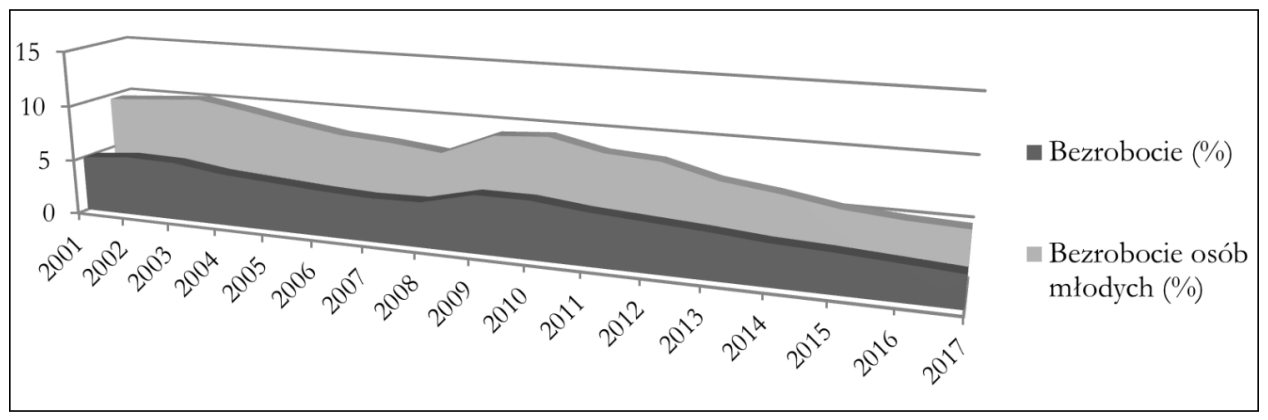

Źródło: [Rocznik statystyczny..., 2017, s. 792-793; Informator ekonomiczny..., 2018; GUS, http:// stat.gov.pl/statystyka-miedzynarodowa/porownania-miedzynarodowe/tablice-o-krajach-wedlu g-tematow/rynek-pracy/, data wejścia: 14.04.2018].

Według oficjalnych japońskich statystyk stopa bezrobocia w kraju w latach 2005-2016 spadła z 4,4\% do 3,1\% i była najniższa w gronie krajów OECD. Jeszcze niższe w skali światowej okazuje się bezrobocie osób młodych, to jest w wieku od 16 do 24 lat. W okresie 2005-2016 wskaźnik ten w Japonii zmalał 
z 8,7\% do zaledwie 5,1\%, dzięki czemu Japonia znalazła się na ostatnim miejscu wśród krajów OECD. Bardzo niskie w skali światowej bezrobocie w Japonii jest częściowo spowodowane znacznym odsetkiem osób w wieku powyżej 65 lat oraz niespotykanym w skali światowej etosem pracy, łączącym życie zawodowe i prywatne, co niekiedy prowadzi do pracoholizmu [Rocznik statystyczny..., 2017, s. 792-793].

\section{Sytuacja fiskalna Japonii}

Jednym z najpoważniejszych problemów sektora finansów publicznych Japonii jest utrzymujące się na bardzo wysokim poziomie zadłużenie krajowe oraz deficyt budżetowy. Deficyt sektora finansów publicznych towarzyszy gospodarce japońskiej od 1975 roku, z kilkuletnią przerwą u schyłku lat osiemdziesiątych i na początku lat dziewięćdziesiątych. W kolejnych zarówno dług publiczny, jak i deficyt budżetowy systematycznie rosły, a stan sektora finansów publicznych uległ zdecydowanemu pogorszeniu po wybuchu globalnego kryzysu w 2008 roku. Akumulacja deficytów budżetowych doprowadziła do największego $\mathrm{w}$ gronie krajów OECD wzrostu długu publicznego $\mathrm{w}$ relacji do PKB. W 2016 roku oficjalnie dług publiczny Japonii pierwszy raz w historii przekroczył 250\% PKB (250,4\%), a według wstępnych danych za 2017 roku przekroczył 253\% dochodu narodowego. „Lwią” część japońskiego długu publicznego od lat stanowi zadłużenie w formie obligacji (850 bilionów jenów

WYKRES 5

Finanse publiczne Japonii w latach 2001-2015 (mld jenów)

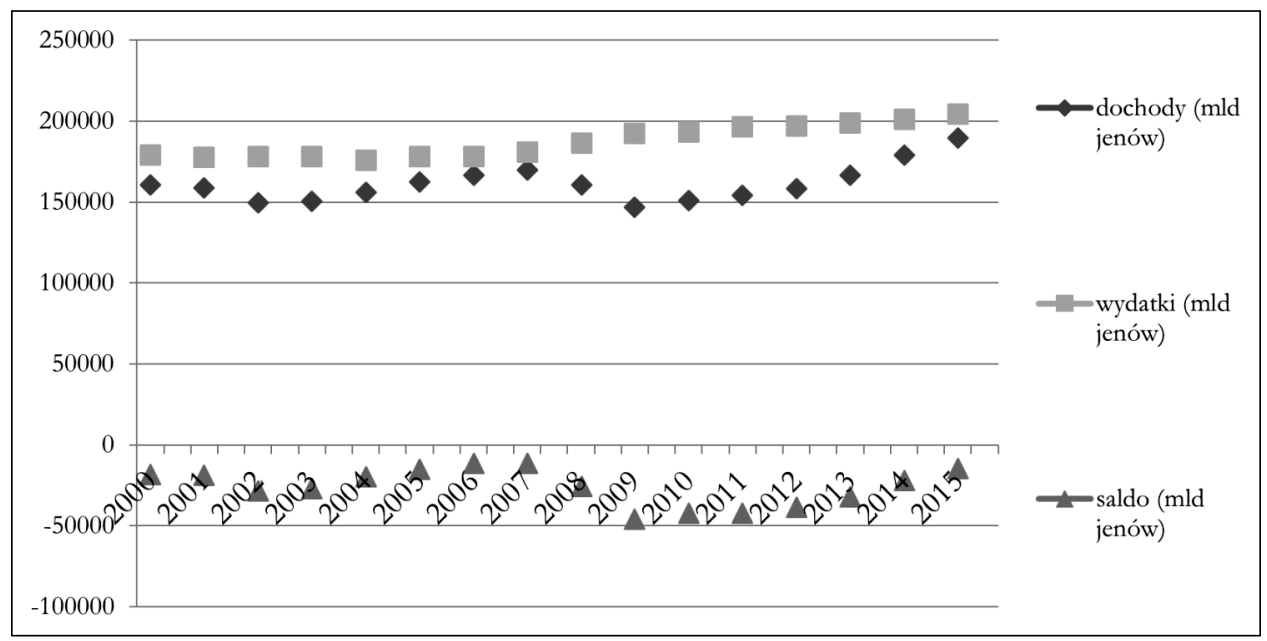

Źródło: [GUS, http://stat.gov.pl/statystyka-miedzynarodowa/porownania-miedzynarodowe/ tablice-o-krajach-wedlug-tematow/finanse/, data wejścia 13.04.2018]. 
w 2015 roku). Bardzo dużą część wydatków budżetowych pochłania obsługa długu krajowego (42\% w 2015 roku). Szacunki Międzynarodowego Funduszu Walutowego prognozują dalszy wzrost długu publicznego w nadchodzących latach do nawet 300\% dochodu narodowego w 2030 roku [Mrowiec, 2017, s. 192-200].

Cechą charakterystyczną sektora finansów publicznych jest niskie w porównaniu z wieloma innymi krajami wysoko rozwiniętymi zadłużenie zagraniczne. Jest to spowodowane tym, że około $95 \%$ nabywców obligacji państwowych to krajowi inwestorzy, w większości banki, firmy ubezpieczeniowe oraz fundusze emerytalne. Zdaniem autora $\mathrm{w}$ najbliższych latach przepływy pieniężne $\mathrm{z}$ dużych instytucji finansowych będzie maleć, w związku z szybkim starzeniem się społeczeństwa, co spowoduje także znaczny spadek możliwości wewnętrznego zadłużania się przez rząd i koniecznością stanie się znalezienie potencjalnych zagranicznych nabywców japońskich obligacji, co może nie być łatwe. Autor podkreśla też wysoki stopień ryzyka utraty kontroli nad zadłużeniem kraju przez rząd, a to może mieć katastrofalne skutki dla wielu krajów wysoko rozwiniętych [Mrowiec, 2017, s. 197-200].

TABELA 2

Deficyt budżetowy i dług publiczny Japonii w latach 2010-2017 jako \% PKB

\begin{tabular}{|c|c|c|c|c|c|c|c|}
\hline \multirow{2}{*}{ Wyszczególnienie } & \multicolumn{7}{|c|}{ Rok } \\
\cline { 2 - 9 } & 2012 & 2013 & 2014 & 2015 & 2016 & 2017 & 2018 \\
\hline Deficyt budżetowy [\% PKB] & $-7,9$ & $-8,3$ & $-5,8$ & $-6,7$ & $-5,2$ & $-5,1$ & $-2,4$ \\
\hline Dług publiczny [\% PKB] & 238 & 244,5 & 249,1 & 248 & 250,4 & 239 & 239 \\
\hline
\end{tabular}

Źródło: [Japonia. Informacja..., 2017, s. 1; Informator ekonomiczny..., 2018].

W 2016 roku w rękach Banku Japonii znajdowało się aż 38 procent wszystkich kupionych obligacji rządowych, podczas gdy w 2012 roku było to zaledwie 13 procent. Nic nie wskazuje na to, aby sytuacja ta miała w najbliższym czasie ulec zmianie, gdyż Bank Japonii w 2016 roku zapowiedział kontynuację programów skupu aktywów. Gdy bierzemy pod uwagę dług nominalny w relacji do nominalnego PKB, Japonia od lat zajmuje pod tym względem pierwsze miejsce na świecie. $W$ praktyce dług publiczny posiadany przez bank centralny często nigdy nie musi być spłacony. W tym przypadku w 2016 roku rzeczywisty stosunek długu publicznego Japonii w relacji do dochodu narodowego wyniósł 142 procent PKB i był niższy, niż w Grecji (177\% PKB). Mimo systematycznego wzrostu poziomu zadłużenia sektora finansów publicznych, rząd w dalszym ciągu preferuje zadłużanie się $u$ własnych obywateli i krajowych instytucji finansowych, niż poza granicami kraju, przez co udział zadłużenia zagranicznego Japonii $\mathrm{w}$ zadłużeniu ogółem $\mathrm{w}$ dalszym ciągu jest nieduży. Japończycy od lat na- 
leżą do największych wierzycieli świata [http://www.rp.pl/Dane-gospodarcze/ 170229103-Polski-dlug-w-rekach-zagranicznych-Uczmy-sie-od-Japonii.html, data wejścia: 13.04.2018; https://www.pb.pl/rekordowe-zadluzenie-japonii-to-fikc ja-wykres-dnia-850190, data wejścia: 13.04.2018].

\section{Podsumowanie}

Po przeanalizowaniu dużej liczby publikacji naukowych dotyczących gospodarki japońskiej należy stwierdzić zdecydowaną przewagę czynników zewnętrznych nad uwarunkowaniami wewnętrznymi wśród głównych przyczyn regresji ekonomicznej tego kraju. Pierwsza hipotezę szczegółową należy zweryfikować pozytywnie, gdyż głównym problemem japońskiego sektora finansów publicznych jest utrzymujący się od wielu lat i stale rosnący deficyt budżetowy oraz drugi najwyższy w skali światowej realny dług publiczny $\mathrm{w}$ relacji do PKB (po Grecji). Do weryfikacji drugiej hipotezy szczegółowej należy odnieść się z dystansem, gdyż polityka migracyjna otwartych granic, prowadzona współcześnie przez kraje Europy Zachodniej i Północnej, w ostatnich latach dała negatywne skutki w postaci znacznego spadku poziomu bezpieczeństwa wewnętrznego i zewnętrznego. Wydaje się jednak, iż starzejące się w bardzo szybkim tempie japońskie społeczeństwo musi stać się bardziej otwarte dla cudzoziemców, niż jest obecnie. Istnieje wiele racjonalnych argumentów na rzecz większej otwartości rynku pracy dla imigrantów, jak np. bardzo niskie bezrobocie wśród gastarbeiterów, względnie atrakcyjne płace dla zagranicznych pracowników oraz bardzo korzystna struktura wiekowa i zdecydowanie wyższy poziom dzietności wśród imigrantów, w porównaniu z rdzennymi mieszkańcami Japonii. Brak zdecydowanych działań ze strony władz i społeczeństwa w kierunku przezwyciężenia problemów demograficznych kraju może skutkować w niedalekiej przyszłości dalszym spadkiem znaczenia gospodarczego Japonii $\mathrm{w}$ gospodarce globalnej. Mimo wielu czynników ryzyka związanych z przyjmowaniem przez kraj znacznej liczby cudzoziemców, jak spadek bezpieczeństwa publicznego oraz stopniowy zanik miejscowej kultury, wydaje się, iż Japonia powinna prowadzić zdecydowanie bardziej przyjazną politykę wobec imigrantów, głównie z innych krajów Azji Południowo-Wschodniej.

Zupełnie inaczej wygląda sytuacja w przypadku weryfikacji głównej hipotezy, wskazującej jako główną przyczynę wzrostu zadłużenia sektora finansów publicznych Kraju Kwitnącej Wiśni bardzo rozbudowaną politykę społeczną. Japonia może bowiem stanowić wzór w kwestii rozwiązań w polityce społecznej dla wielu krajów azjatyckich, gdyż wydatki budżetowe są tam relatywnie niskie $\mathrm{w}$ porównaniu z większością krajów OECD. Warto również zwrócić uwagę na diametralną poprawę jakości życia Japończyków po 1990 roku oraz fakt, iż nie ma na razie racjonalnych argumentów na rzecz ograniczenia wydatków na politykę społeczną Japonii, głównie ze względu na stale rosnącą liczbę osób starszych. Wiele krajów najwyżej rozwiniętych boryka się także z rela- 
tywnie wysokim długiem publicznym oraz zagranicznym. Ponadto, większość wydatków publicznych Japonii od lat pochłaniają koszty związane z obsługą już istniejącego długu publicznego oraz koszty ubezpieczeń społecznych, co negatywnie wpływa na wielkość deficytu budżetowego kraju. Według wielu naukowców polityka społeczna w Japonii oraz rozmiary sektora publicznego są w tym kraju znacznie mniejsze niż w większości krajów OECD. Dlatego też główną hipotezę badawczą należy zweryfikować negatywnie.

\section{Literatura}

Bank Światowy, dokument elektroniczny, tryb dostępu: [https://data.world bank.org/indicator/NY.GDP.MKTP.KD.ZG?locations=JP, data wejścia:

14.04.2018].

Bank Światowy, dokument elektroniczny, tryb dostępu: [https://data.world bank.org/indicator/NE.IMP.GNFS.CD?locations=JP, data wejścia:

13.04.2018].

GUS, dokument elektroniczny, tryb dostępu: [http://stat.gov.pl/statystyka-mie dzynarodowa/porownania-miedzynarodowe/tablice-o-krajach-wedlug-te matow/finanse/, data wejścia 13.04.2018].

GUS, dokument elektroniczny, tryb dostępu: [http://stat.gov.pl/statystyka-mie dzynarodowa/porownania-miedzynarodowe/tablice-o-krajach-wedlug-te matow/rachunki-narodowe/, data wejścia 13.04.2018].

GUS, dokument elektroniczny, tryb dostępu: [http://stat.gov.pl/statystyka-mie dzynarodowa/porownania-miedzynarodowe/tablice-o-krajach-wedlug-te matow/rynek-pracy/, data wejścia: 14.04.2018].

Grabowiecki J., 2014, Abenomika jako nowa polityka gospodarcza przezwyciężania stagnacji w Japonii, [w:] Nowe procesy w gospodarce światowej: wnioski dla Polski, Budnikowski A., Kuźniar A., Oficyna Wydawnicza SGH, Warszawa.

Grabowiecki J., 2006, Grupy kapitałowo-przemysłowe keiretsu w nowych uwarunkowaniach rozwojowych gospodarki Japonii. Przyczyny regresu, Wydawnictwo UwB, Białystok.

Grabowiecki J., 2009, Japoński model gospodarczy jako wzorzec dla krajów Azji Południowo-Wschodniej, "OPTIMUM. Studia Ekonomiczne”, nr 4 (44).

Grabowiecki J., 2008, Rola państwa i sektora publicznego w Japonii, [w:] Sektor publiczny we wspótczesnej gospodarce, Przygodzka R. (red.), Wydawnictwo UwB, Białystok.

http://www.rp.pl/Dane-gospodarcze/170229103-Polski-dlug-w-rekach-zagrani cznych-Uczmy-sie-od-Japonii.html [data wejścia: 13.04.2018].

https://businessinsider.com.pl/lifestyle/demografia-japonii-czy-japonczycy-mo ga-wyginac/cyw8dec [data wejścia: 01.04.2018].

https://www.pb.pl/rekordowe-zadluzenie-japonii-to-fikcja-wykres-dnia-850190 [data wejścia: 13.04.2018]. 
Informator ekonomiczny MSZ: Japonia, dokument elektroniczny, tryb dostępu: [http://www.informatorekonomiczny.msz.gov.pl/pl/azja/japonia/, data wejścia: 14.04.2018].

Japonia. Informacja o stosunkach gospodarczych z Polska, 2017, Ministerstwo Przedsiębiorczości i Technologii, Departament Handlu i Współpracy Międzynarodowej, Warszawa.

Młodawska-Bronowska J., 2014, Innowacje w Japonii w warunkach spowolnionego wzrostu gospodarki. Jaka powinna być polityka makroekonomiczna?, [w:] Współczesna Japonia - dylematy $i$ wyzwania, Marszałek-Kawa J., Skonieczka K., Wydawnictwo Adam Marszałek, Torun.

Młodawska-Bronowska J., 2017, Jak wyjść z pułapki wieloletniej stagnacji? Japońskie realia 2016, [w:] Japońskie realia. Polityka i gospodarka, Marszałek-Kawa J., Bodio T., Wydawnictwo Adam Marszałek, Torun.

Mrowiec M., 2017, Austriacka Szkoła Ekonomii. Jak może pomóc wyjaśnić stagnacje gospodarki Japonii, PWN, Warszawa.

Mydel R., Takahashi D., 2013, Cudzoziemscy pracownicy na japońskim rynku pracy, [w:] Społeczno-ekonomiczne przemiany regionów, Raźniak P. (red.), Oficyna Wydawnicza AFM, Kraków.

Pieliński B., 2013, Między Japonia a Singapurem. Rozwój polityki społecznej w Azji Wschodniej, Wydawnictwo Elipsa, Warszawa.

Rocznik statystyczny Rzeczypospolitej Polskiej 2017, 2017, Główny Urząd Statystyczny, Warszawa.

This World: The Great Japanese Retirement, 2013, film dokumentalny, reż. J. Holdsworth, Wielka Brytania.

Tomeczek A.F., Tomeczek M., 2017, Ekonomiczne i polityczne uwarunkowania współpracy gospodarczej Japonii i Unii Europejskiej, [w:] Japońskie realia. Polityka i gospodarka, Marszałek-Kawa J., Bodio T., Wydawnictwo Adam Marszałek, Toruń 2017. 